\title{
THE CHECKERED PATTERN OF UNITED STATES - TURKEY RELATIONS IN AK PARTY ADMINISTRATION
}

\author{
Dr. Metin AKSOY \\ Selcuk University
}

\begin{abstract}
Historically, the United States-Turkey relations followed a checkered pattern notably in the aftermath of the World War II when direct political intercourses commenced in earnest. Throughout the Cold War, Turkey implicitly acted as the outpost of American-led Western World against the then omnipresent threat of Soviet expansion, thereby pursuing a foreign policy concurrent with US expectations. Though Turkey was highly regarded as an ally, it was left in the lurch on many occasions by American policymakers, which bruised the spirit of the alliance and generated an atmosphere of mistrust in bilateral relations. Likewise, the bilateral relations in the wake of the Cold War era might be characterized with consecutive thaws and tensions as the demise of the Soviet threat paved way for more independent Turkish foreign policy. Toward and after the turn of the millenium, the bilateral relations were identified with more conceptual terms like "strategic partnership". However, from the very inception of the AK Party tenure hitherto, the trajectory of relations has taken on a new and unprecedented dimension as Turkey has become a regional power of greater potency and been in search of a more ranking position on the global and regional scale.
\end{abstract}

Keywords: US-Turkey Relations, AK Party, International Relations.

\section{INTRODUCTION}

At the turn of the new millenium, Turkey-US relations benefited the final phase of the "strategic partnership" which had been established long ago during the Cold War era. The bilateral relations, surviving the spells of rift in and after the cold war, reached at the first decade of the $21^{\text {st }}$ century in a moderate atmosphere. However, a set of watershed events brought a seachange in the course of the relations.

Not long after the inauguration of Bush as the President in 2000, the world as well as American community were taken aback by the notorious $9 / 11$ terrorist events, which led to a drastic shift in the US foreign policy. With the establishment of the preemptive strike doctrine introduced by Bush administration, USA waged war on terrorism on a global scale. (Terzi, Sonmezoglu \& Baklacioglu, 2012, 323-325) This paved the way for US security policy to be centered upon the tinderbox of terrorist organizations notably in the Middle East, thereby initi- 
ating the Operation Enduring Freedom to overthrow the Taliban regime in Afghanistan. The next phase of the war on terrorism targeted the country of Iraq, which gave momentum to US-Turkey relations since Turkish stance on the prospective US moves became of greater concern for American policymakers. (Dagci, 2012, 1-2)

\section{BUSH'S TENURE: RESUMPTION OF THE EXISTING "STRA- TEGIC PARTNERSHIP"}

American demands for military cooperation with Turkey coincided with the preliminary months of the AK Party tenure. The resolution of utilization of Turkish territory as military bases for US troops in the Iraqi operation was voted in Turkish Parliament and the bill named "Deployment of Turkish Armed Forces Abroad and Deployment of Foreign Forces in Turkey" was rejected on 2003, March 1st.

Turkish Parliament's veto on accommodation of US combatant troops in Turkey created mutual crisis and was said by many to have led to the demise of the former "strategic partnership." The tension grew higher with the iniquitous apprehension of Turkish military personnel in Iraq by US troops. Hoods were placed over the heads of Turkish soldiers in a way that later was regarded as an insult to Turkish national pride. The ostensible reason for such a practice was the search of retaliation against the Bill of March 1st. The incident, coupled with the aggressive stance of Bush administration on the Middle Eastern countries, created a great backlash in Turkey and anti-American public opinion rocketed in Turkish community.

The bilateral relations suffered from an atmosphere of mutual mistrust till the year of 2006 when action was taken to redeem the said negative atmosphere. Both states became signatory to an agreement initiated under the heading "Shared Vision and Structured Dialogue" by Turkish Foreign Ministry and US Secretary of State. (Dagci, 2012, 4-5) This initiative was allocated much hype in the media with US Secretary of State Condoleezza Rice saying: "Sometimes it's very important to

Inquiry step back from the day-to-day issues and to look at the broad relation2016/2 ship, and to remind ourselves and to remind our populations that this is a relationship that is broad and deep and based on values and based on strategic interests, and that's really what this document allows us to do." and Turkish Foreign Minister Abdullah Gul putting it: "The shared vision document will enable our countries to conduct close and intensive consultations on many levels; it will provide for a structured dialogue; it will enable us to address more effective the issues of bilateral, regional and international concern." (Enginsoy, 2006)

The document was an instrument of the policy of reviving the 
formerly damaged "strategic partnership". With the document, both countries pledged themselves to work together on all issues of common concern, including promoting peace and stability in the broader Middle East through democracy, supporting international efforts towards peaceful settlement of all regional conflicts, improving the energy security in the region and fighting against terrorism and PKK in earnest.

Notwithstanding this common ground, the following period was a time of fragility for Turkish-American relations. In Turkey, AK Party emerged victorious in the national elections of 2007, July, consolidating its position in Turkish political system by garnering nearly half of the votes of the electors. Meanwhile, a terrorist attack on Turkish Armed Forces by PKK terrorist organization in October had become the last straw before Turkish Parliament passed a bill permitting the crossborder military operation against PKK bases in Northern Iraq. US top brass adopted a stance against the prospective operation stating that it would harm Iraq's stability. This stance created back again a state of mistrust, bruising the transient positive atmosphere created by the Shared Vision and Structured Dialogue. Subsequently, in PM Erdogan's official visit to White House in November, Bush administration pledged to open Iraqi airspace to Turkey and provide intelligence and cooperation against PKK, which served to the moderating of the prevailing tension.

In 2007, the state of Turkish-American relations deteriorated owing to another issue. Similar to the previous attempts back in 2000 and 2005, US House of Representatives' International Relations Committee passed Armenian Genocide legislation to recognize the allegations and reflect them in US foreign policy. The legislation was delivered to the Congress as a proposal. At this point, the Speaker of Turkish Parliament sent a letter to the Speaker of the Congress stating that the passage of the bill through Congress would harm Turkish-American relations as well as it would escalate the ongoing latent crisis between Turkey and Armenia. (Dagci, 2012, 4-5)

In Bush's tenure, the state of Turkish-American relations was observed to have followed a checkered pattern. Even at times of escalating crisis, US top brass could not afford the further deterioration of the bilateral relations. This was mainly due to US expectations from Turkey. For the "Greater Middle East Initiative" project by Bush administration with a view of restructuring the Middle East in line with US interests by systematically promoting and enforcing democracy in non-democratic countries of the region; Turkey, with its Muslim, secular and democratic identity, was designated as the model country for the initiative. Both countries had common interests in the stability of Middle East, fight 
against terrorism, security of regional energy streams. This rendered Turkey an indispensable strategic ally. However, the eventual failure of the military operations both in Afghanistan and Iraq raised questions about the sustainability of the initiative and Turkey's role in the project. (Dagci, 2012, 6)

\section{OBAMA'S TENURE: TRANSITION TO 'MODEL PARTNER- SHIP" AND INTERMITTENT FAILURES}

During George W.Bush's reign, the international society had become disgusted of the repercussions of his foreign policy moves and the world had been in quest of a new phase in US political history. The relief came when Barrack Obama was inaugurated as the new US president in 2009. With the emphasis he had made on bringing up a radical change, the societies of the world states including that of Turkey regarded Obama as the embodiment of a more favourable way of governing.

Obama's foreign policy vision was in no compliance with that of Bush's. Left with the remnants of the conflicts and issues of Bush's term, he abandoned his predecessor's aggressive policies on Middle East and was intent on pursuing policies concurrent with the international consensus.

In Obama's foreign policy vision, the USA partly preserved the status quo in the Middle East and relatively directed its leverage and attention to Asia-Pasific region, thereby leaving a latent power vacuum in the region where regional actors, especially Turkey and Iran, could pursue more independent foreign policies. In compliance with this trend, Ankara expected the abrogation of the asymmetrical feature of bilateral relations with Washington and aspired both parties to behave as equal actors and partners with the focus shifting from security-military issues to multifaceted issues. Besides, Obama initially renounced Bush's earlier policy of "you are either with us or against us" toward its allies. In this regard, Obama administration tolerated the differences with its ally Turkey and sought to consolidate the cooperation and partnership with Ankara despite the existence of these differences. These rationales put forward a mutual will to bring the bilateral relations to a new dimension. (Kurtbag, 2015, 187-189)

With the inception of AK Party's second governmental term, which coincided with Obama's presidential inauguration, Turkish foreign policymakers led by the new Foreign Minister Ahmet Davutoglu under the AK Party Government adopted a tendency to conduct policies through underlying principles coded with the terms of rhythmic diplomacy, multi-dimensional foreign policy, zero problems with neighbors, order in- 
stituting actor, international cooperation and proactive foreign policy. Determined to eliminate the all-encompassing misconception that Turkey had only been performing the roles assigned by global designers of regional politcs, the new policymaking cadre determined a political vision and set out to execute foreign policy in line with national priorities. Through this new vision, Turkey rejected the preoccupation with pursuing the traditional ties with West World and sought to diversify the foreign relations by reestablishing and enforcing economic, diplomatic and political relations with countries in the region of late-Ottoman territories, which was criticized by many and considered to be an axis shift in foreign policy. (Davutoglu, 2012, 3-5)

Parallel to the search of autonomy in foreign policy attitudes by Turkish governmental top brass, Obama administration felt a need to redefine the framework of bilateral relations. As President, Obama paid his first transoceanic visit to Turkey with a view to reestablishing the damaged relations during Bush period. This visit was very constructive in terms of gaining a new dimension in Turkish-American relations. In his visit, Obama declared his high opinions of Turkey and the visit was welcomed by many. In his speech delivered before the members of Turkish Parliament, Obama put it as: "The United States and Turkey have not always agreed on every issue, and that's to be expected - no two nations do. But we have stood together through many challenges over the last 60 years. And because of the strength of our alliance and the endurance of our friendship, both America and Turkey are stronger and the world is more secure." (Han, 2010, 98-101)

Obama's foreign policy understanding regarded Turkey as a "model partner" as opposed to "strategic partner". Strategic partnership, as a concept, had meant a kind of alliance in which both countries acted together against a common threat on military and intelligence base. Model partnership, on the other hand, did not indicate a reciprocally agreed framework but renounced the hierarchical structure of bilateral relations and rendered the two parties equal. (Dagc1, 2012, 8) All in all, though utilized in the speeches delivered by the top brass of both parties, the term "model partnership" remained vague and the political developments transpiring in the following period when Ankara and Washington didn't see eye to eye raised concerns over the sustainability of the new dimension of alliance conceptualized with this term.

In May 2010, Turkey and Brazil announced a fuel-swap deal with Iran. The Tehran Declaration stipulated that enriched nuclear fuel was to be provided to Iran in exchange for dipositing 1,200 kilograms of low-enriched uranium to Turkey. (Turkish Ministry of Foreign Affairs, 2010) The USA and other global political actors were left in consterna- 
tion that enriched fuel would enable Iran to further enrich uranium and attain the level necessary to construct a nuclear weapon more rapidly. (Gurzel, 2012) Nearly a month later, Turkey voted against the UN sanctions on Iran in United Nations Security Council, which, coupled with the earlier deal, sufficed to damage the bilateral relations with USA. (Ozerkan, 2010) However, at NATO summit of November 2010 in Lisbon, Turkey accepted US demands of placing the military radars in Turkish territories under the new missile defense project at the expense of damaging the relations with Iran, which was considered by many to be an act in favour of the atmosphere created by the declaration of "model partnership." (Kurtbag, 2015, 193)

Principally owing to the influential activisms of Jewish lobby in American policymaking institutions, the well-being of Turkey-US relations had always been riding on Turkey's relations with Israel, as was the case back in 2009-2010. Israel committed atrocities on Muslims during and following the Gaza War in 2008-2009, for which many of the world communities remained silent. Turkey, on the contrary, raised objections to the humanitarian drama transpiring in Gaza owing to the Israeli-imposed blockade. It came as much of a surprise to the international communtiy when Turkish Prime Minister Erdogan stood up at Davos Summit in 2009 and slammed Israel for its unilateral Palestine policy and acts of civil rights violations. Besides, Turkey's mediation efforts to whittle away at the provocative policies of Israel could not produce the expected results. (Ozhan, 2010, 10)

In addition, Turkish and American policymakers didn't see eye to eye on the unfolding of the events in Palestinian-Israeli conflict. One important difference in this regard was the assessment of Hamas. USA recognized Hamas as a radical terrorist organization while Turkish assessment of the group remained relatively more subtle. While such a difference existed, the international community heard of the news of Israeli army attacking an international humanitarian aid flotilla sailing from Turkey en route to Gaza. Israel had breached international law by carrying out military operation in international waters and killing and injuring the passengers. The incident directed the attention of international community to the broader issue of Gaza blockade and great backlash came from the international public opinion. However, US top brass shared the view that Israel had utilized its right of self-defense by conducting military operation on the flotilla and even the earlier Gaza blockade had been an act of self-defense. (Wexler, 2010, 9-11) US stance on the issue caused much damage to Turkey-USA relations as anti-American sentiment grew in the Muslim community of Turkey.

Meanwhile, in the wake of the outbreak of Arab spring, Turkey 
adopted a stance consonant with the expectations of Washington by utterly supporting Egyptian community against Mubarak regime and reluctantly favoring the NATO intervention against Gaddafi regime in Libya. In Egypt, after the fall of Mubarak regime, Turkey had advocated Muslim Brotherhood and in the national elections Moursi had been elected as the President. Toward the end of 2013, General Abdul Fattah al-Sisi staged and achieved a presidential coup. Subsequently, a disagreement emerged between Ankara and Washington over the legitimacy of the coup. While Turkey raised political objections to the foundation of Sisi-administration, Washington didn't even name the event as a coup and claimed the coup to be legitimate in establishing democracy in the country. This difference disrupted the earlier thaw in the bilateral relations.

The same year, Turkey announced plans to purchase Chinese-made air-defense systems, which mounted the tension between Ankara and Washington. USA and other NATO allies voiced concerns over a member state's integration of Chinese-made hardware into NATO's defence architecture. This controversial issue stemmed from Turkey's concerns for being left alone in the face of regional threats and the search of diversifying the arms technology. However, apart from the tension it created, the issue brought together other political interactions with West states and notably USA. (Kurtbag, 2015, 199-200)

A set of domestic political developments inside Turkey escalated the state of crisis in relations with USA. Turkish Government's tough stance against Gezi Protests and so-called use of violence reawakened civil rights concerns of the West, notably the American Community. US top brass officially condemned the use of violence and criticized the statements of Turkish political leaders, notably PM Tayyip Erdogan, in which some Jews-led shadowy interest groups were blamed for the unrest (Zanotti, 2015, 29). Subsequent to December 17th incident of corruption-related arrests of Turkish businessmen having close ties with the government, Turkish government officials blamed Gulen Movement for bringing the corruption charges due to political motivations (Onar, 2016, 7). At presidential level, Turkey demanded extradition of Fethullah Gulen, the leader of the movement residing in USA; however the US officials did not comply with the request on the grounds of insufficiency of the evidence of Gulen movement's wrongdoings, which created another atmosphere of mistrust in Turkey-US relations (Zanotti, $2015,5)$. In addition, USA became much attuned to the later domestic political developments in Turkey. US officials expressed at every opportunity concerns regarding civil liberties and political instabilities. In the first half of 2015, US Senate sent letters to Turkey condemning the 
so-called media repression and censorship (Zanotti, 2015, 8) and such statements and interventions by US officials only fueled the tension in the relations.

As for the foreign agenda, in the second phase of the Arab spring, Turkey's split with Assad regime in the wake of the uprisings that occured in Syria was welcomed by Washington on the grounds that Turkey was willing to stand with the West on the issue. However, US top brass mistrusted Ankara suspecting the Anti-Assad stance to be an instrument of bringing Sunni factions into a position of control in Syria (Falk, 2014, 15).

\section{BILATERAL RELATIONS IN THE LIGHT OF THE LATEST DEVELOPMENTS IN TURKEY'S VICINITY}

During the course of the Syrian conflict, Obama administration primarily chose to abstain from undergoing a costly military operation and proposed the settlement of the conflict through peace talks. (Kurtbag, 2015, 196) American "wait-and-see" policy was undermined by later developments and the upsurge of the threat by the Islamic State of Iraq and Levant (ISIL). From 2013 to late 2014, the Islamic State established a power base in Syria and achieved total control of the adjacent regions to its stonghold of Raqqa. Gaining the upperhand in the confrontations with other rebel groups of different causes, the group consolidated its military power by use of policies of divide and rule in tribal communities of the region. Concurrent with the advancement of leverage in Syria, the organization managed to take control of the parts of important Iraqi cities such as Fallujah and Ramadi. In June, Iraq's second biggest city Mosul was captured by the Islamic State much to the consternation of the world political communities. On June 29, 2014, the Islamic State proclaimed the caliphate and demanded staunch support from all Muslims throughout the world. (Blanchard\&Humud, 2016, 6-7) US "wait-and-see" policy was abrogated in the face of the ISIL threat. US-led coalition powers conducted air strikes against ISIL while still abstaining from direct ground military operation to Syria.

In efforts of keeping ISIL's territorial expansion in check and undermining its regional leverage, USA sought to consolidate the positions of other militia groups, notably Kurdish Militia in Syrian territories. PYD (the Democratic Union Party) was singled out as a local ally in the fight against the ISIL, which contradicted with the Turkish regional interests and mounted the state of alarm in Turkish threat perception against Kurdish movement in Syria. (Zanotti, 2016, 7-8)

Earlier, PYD had emerged as one of the strongest warring parties in the Syrian turmoil and ultimately proclaimed the so-called political 
autonomy in the Rojava region (Syrian Kurdistan) of three cantons: Efrin, Kobanê and Cêzîre. This de facto Kurdish Authority adjacent to its territories was not welcome by Turkey on the grounds of PYD's close association and affiliation with PKK. (Ozturk, 2014, 77-79)

USA has recognized PKK as a terrorist organization since 1997 but PYD has not yet been regarded a terrorist organization. Latest US political and military support for PYD has irritated Turkey. American envoy Brett McGurk's visit to Kobani in January 2016 became the last straw for Turkey. (Arslan, 2016) President Erdogan, in retaliation, said: "How can we trust you? Is it us that is your partner or is it the terrorists in Kobani?" (Ochoa, 2016) The feud deepened when US officials rejected Turkish claims of US weapons procurement to PYD and arms smuggling transpiring from PYD to PKK. Later Russion support for PYD as well coupled Turkey's solitude in the stance against Syrian Kurds, and later developments occured parallel to this status quo.

\section{CONCLUSION AND THE WAY AHEAD}

Historically, US policy toward Turkey had only been a by-product of policies toward the entire region, a tradition which was later amended by the rule of AK Party. No other government in Turkish political history has pursued more independent foreign policy than AK Party governments. Under AK Party rule, Turkey has earned more potency and become more influential on the regional and global scale with the unprecedented foreign policy understandings introduced by the party. Disavowing the inferior role assigned by Western powers, Turkey has managed to ascend to the position of USA's equal partner and ally in joint foreign policy moves. However, it is still an ongoing routine that USA leaves Turkey in the lurch on the regional issues every so often while prudently abstaining from undergoing acts which may alienate Turkey in earnest. Turkey's relations with USA through recent developments should be assessed in this regard.

At the current juncture, the atmosphere of the bilateral relations is contingent upon the prospective regional developments. The mutual stance adopted in the Syrian conflicts as well as the Kurdish issue and conformity of Turkey's domestic political developments to US expectations will be the determinants of the new atmosphere.

It remains to be seen how the new developments in Iraq and Syria will affect bilateral relations and what will president-elect Trump's policies be like towards Turkey. 


\section{REFERENCES}

Arslan Rengin, “Turkiye-ABD Soz Duellosunun Perde Arkasi”, http://www.bbc. com/turkce/haberler/ 2016/02/160212_abd_turkiye [Accession 04.11.2016]

Blanchard Christopher M., Humud Carla E. (2016), "The Islamic State and U.S. Policy", Congressional Research Service Publishing.

Dagci Gul Tuba (2012), “Turkey-US Relations in Justice and Development Party's Era”, Alternatives: Turkish Journal of International Relations, Vol. 11, No.2.

Davutoglu Ahmet (2012), "Principles of Turkish Foreign Policy and Regional Political Structuring”, Turkey Policy Brief Series, International Policy and Leadership Institute.

Enginsoy Umit (2006), “Turkey, US Invest Hopes In Shared Vision Document” http:// www.hurriyetdailynews.com/turkey-us-invest-hopes-in-shared-vision-document. aspx?pageID=438\&n=turkey-us-invest-hopes-in-shared-vision-document-2006-07-07 [Accession 07.11.2016]

Falk Richard (2014), "Can the U.S. Government Accept an Independent Turkish Foreign Policy in the Middle East?", Insight Turkey Vol.16/No.1.

Gurzel Aylin (2012), “Turkey's Role in Defusing the Iranian Nuclear Issue”, The Washington Quarterly.

Han Ahmet K (2010), "From "Strategic Partnership" to "Model Partnership" : AKP, Turkish-US Relations and the Prospects Under Obama", UNISCI Discussion Papers, Vol.23.

Kurtbag Omer (2015), "Turkish-American Relations under Obama: Ups and Downs and Diverging Interests from the Model Partnership to the Axis Shift Debate" , Research Journal of Politics, Economics and Management, Year:3, Volume:3, No:2.

Nissenbaum Dion, Lee Carol, "Turkish Tensions With Syrian Kurdish Fighters Strain Ties With U.S.”, http:/www.wsj.com/articles/turkish-tensions-with-syriankurdish-fighters-strain-ties-with-u-s-1454892749 [Accession 08.11.2016]

Ochoa Dolores, "Erdogan: U.S. Should Choose Between Turkey, Kurdish Forces" , http://www.usnews.com/news/world/articles/2016-02-07/erdogan-us-shouldchoose-between-turkey-kurdish-forces [Accession 05.11.2016]

Onar Nora Fisher (2016), “The Populism/Realism Gap: Managing Uncertainty in Turkey's Politics and Foreign Policy", Turkey Project Policy Paper Number 8, Center on the US and Europe at Brookings.

Ozerkan Fulya (2010), “Turkey's no vote on Iran sanctions a 'strong rebuke,' former US politician says", http://www.hurriyetdailynews.com/default.aspx?pageid $=438 \& n=$ turkey 8217 s-no-vote-on-iran-sanctions-was-a-strong-rebuke-2010-06-16 [Accession 07.11.2016]

Ozhan Taha (2010), "Turkey, Israel and the US in the Wake of the Gaza Flotilla Crisis", Insight Turkey Vol.12/No.3.

Ozturk Abdullah (2014), “Turkey's Relations with Syria in the Context of the Kurdish Issue: 1980-2014”, A thesis of Mastering Degree, METU.

Terzi Ozlem, Sonmezoglu Faruk, Baklacioglu Nurcan Ozgur (2012), “XXI. Yuzyilda 
Turk Dis Politikasinin Analizi”, Ankara:Der Publishing.

Turkish Ministry of Foreign Affairs (2010), http://www.mfa.gov.tr/17_05_2010-jointdeclaration-of-the-ministers-of-foreign-affairs-of-turkey_-iran-and-brazil.en.mfa [Accession 04.11.2016]

Wexler Robert (2010), “United States and Turkey:Allies at Odds?”,Insight Turkey Vol.12/No. 4.

Zanotti Jim (2015), “Turkey: Background and U.S. Relations”, Congressional Research Service, October 5. https://www.fas.org/sgp/crs/mideast/R41368.pdf [Accession 06.11.2016]

Zanotti Jim (2016), “Turkey: Background and U.S. Relations in Brief”, Congressional Research Service, March 18. https://www.fas.org/sgp/crs/mideast/R44000.pdf [Accession 07.11.2016] 
